Bond University

Research Repository

\title{
Public use and perceptions of emergency departments: A population survey
}

Fitzgerald, Gerry; Toloo, Ghasem Sam; Aitken, Peter; Keijzers, Gerben; Scuffham, Paul

Published in:

EMA - Emergency Medicine Australasia

DOI:

$10.1111 / 1742-6723.12420$

Licence:

Other

Link to output in Bond University research repository.

Recommended citation(APA):

Fitzgerald, G., Toloo, G. S., Aitken, P., Keijzers, G., \& Scuffham, P. (2015). Public use and perceptions of emergency departments: A population survey. EMA - Emergency Medicine Australasia, 27(4), 336-342. https://doi.org/10.1111/1742-6723.12420

\section{General rights}

Copyright and moral rights for the publications made accessible in the public portal are retained by the authors and/or other copyright owners and it is a condition of accessing publications that users recognise and abide by the legal requirements associated with these rights.

For more information, or if you believe that this document breaches copyright, please contact the Bond University research repository coordinator. 


\section{Title Page}

Title: Public use and perceptions of Emergency Departments: A population survey

Authors:

\begin{tabular}{|c|c|c|c|c|}
\hline Name & $\begin{array}{l}\text { Degrees/ } \\
\text { Fellowships }\end{array}$ & Affiliation & $\begin{array}{l}\text { Department, Institution, City, } \\
\text { State }\end{array}$ & Email \\
\hline $\begin{array}{l}\text { Gerry } \\
\text { FitzGerald }\end{array}$ & $\begin{array}{l}\text { MD, FACEM, } \\
\text { FRACMA }\end{array}$ & Professor & $\begin{array}{l}\text { School of Public Health \& Social } \\
\text { Work, Queensland University of } \\
\text { Technology, Brisbane, Queensland }\end{array}$ & gj.fitzgerald@qut.edu.au \\
\hline $\begin{array}{l}\text { Ghasem (Sam) } \\
\text { Toloo }\end{array}$ & $\mathrm{BA}, \mathrm{MA}, \mathrm{PhD}$ & $\begin{array}{l}\text { Research } \\
\text { Fellow }\end{array}$ & $\begin{array}{l}\text { School of Public Health \& Social } \\
\text { Work, Queensland University of } \\
\text { Technology, Brisbane, Queensland }\end{array}$ & sam.toloo@qut.edu.au \\
\hline Peter Aitken & $\begin{array}{l}\text { MBBS, } \\
\text { FACEM, } \\
\text { EMDM, } \\
\text { MClinEd }\end{array}$ & $\begin{array}{l}\text { Associate } \\
\text { Professor }\end{array}$ & $\begin{array}{l}\text { College of Public Health, Medical } \\
\text { and Veterinary Sciences, James } \\
\text { Cook University, Townsville, } \\
\text { Queensland }\end{array}$ & peter.aitken2@health.qld.gov.au \\
\hline $\begin{array}{l}\text { Gerben } \\
\text { Keijzers }\end{array}$ & $\begin{array}{l}\text { MSc (Biomed } \\
\text { Health Sci), } \\
\text { MBBS, } \\
\text { FACEM, PhD }\end{array}$ & $\begin{array}{l}\text { - Emergency } \\
\text { Physician } \\
\text { - Assistant } \\
\text { Professor } \\
\text { - Associate } \\
\text { Professor }\end{array}$ & $\begin{array}{l}\text { - Department of Emergency } \\
\text { Medicine, Gold Coast Health } \\
\text { Service District, Gold Coast, } \\
\text { Queensland; } \\
\text { - Bond University, Gold Coast, } \\
\text { Queensland; } \\
\text { - School of Medicine, Griffith } \\
\text { University, Gold Coast, } \\
\text { Queensland; } \\
\text { - Queensland Emergency Research } \\
\text { Collaborative (QERC), Brisbane, } \\
\text { Queensland }\end{array}$ & gerben.keijzers@health.qld.gov.au \\
\hline Paul Scuffham & $\mathrm{BA}, \mathrm{PhD}$ & Professor & $\begin{array}{l}\text { Menzies Health Institute } \\
\text { Queensland, Griffith University, } \\
\text { Brisbane, Queensland }\end{array}$ & p.scuffham@griffith.edu.au \\
\hline
\end{tabular}

\section{Corresponding author:}

Prof. Gerry FitzGerald

School of Public Health and Social Work

Queensland University of Technology

Victoria Park Road. Kelvin Grove Qld 4059

Email: gj.fitzgerald@qut.edu.au

\section{Contributions:}

All authors equally contributed to the conception and design of the work. GT analysed the data; GF and GT prepared the first draft; all authors revised the manuscript critically for important intellectual content; all authors approved the final version to be published; and all authors agree to be accountable for all aspects of the work in ensuring that questions related to the accuracy or integrity of any part of the work are appropriately investigated and resolved.

\section{Competing interests}

Gerry FitzGerald, Peter Aitken, and Gerben Keijzers are members of the EMA Editorial Board. 


\begin{abstract}
Objectives: To inform demand management strategies aimed at reducing congestion in emergency departments (EDs) by: (i) identifying public use of EDs, decision-making and reasons; and (ii) measuring acceptance of alternative care models.
\end{abstract}

Methods: A cross-sectional telephone survey of a random sample of Queensland population aged 18 years or older residing in a dwelling unit in Queensland that could be contacted on a land-based telephone service was conducted. One person per household was selected according to a predetermined algorithm to ensure gender and regional balance was interviewed. The main outcome measures were: ED use, attitudes towards ED staff and services, and alternative models of care.

Results: The final sample included a total of 1256 respondents (response rate $=40.3 \%$ ). $21 \%$ attended EDs in the preceding 12 months. The decision to attend was made by patients (51\%), health and medical professionals (31\%), and others (18\%). The main reasons included perceived severity of the illness (47\%), unavailability of alternative services (26\%) and better care $(11 \%)$. Most respondents agreed with more flexible care models of service delivery including incentives for GPs (90\%), private health insurance coverage for ED use (89\%) and enhanced roles for paramedics and nurses.

Conclusions: Main reason for attending ED is perceived severity of illness, followed by lack of alternative care. The majority of both consumers and the public are in favour of more flexible care models. However, further research is necessary to detail those alternatives and to test and validate their effectiveness.

\title{
Keywords:
}

Emergency departments; demand; population survey; public perspective; models of care 


\section{Introduction}

Congestion of Emergency Departments (EDs) in Australia and other countries is a cause of public and professional concern. ${ }^{1,2}$ Congestion is associated with significant adverse clinical impacts as well as staff and patient distress. ${ }^{3-5}$ This congestion is in turn caused by growth in demand and "blocked access" to inpatient beds to facilitate the patient's admission to hospital. ${ }^{6}$ However to date public policy responses have not reflected an in depth understanding of the factors that are causing the growth in demand nor do they reflect an understanding of the public's perspectives. Indeed much of the public debate seems to focus on the "inappropriateness" of such growth ${ }^{7-9}$ and the public's perceptions have largely been ignored. $^{10}$

Previous research demonstrates that the average ED utilisation rate in Australia is more than $30 \%$ and this rate is growing by $2 \%$ per annum. ${ }^{11,12}$ Factors that affect this demand include independent factors such as population demographics (particularly ageing of the population) and socio-economic status. These independent factors are moderated by context specific issues such as health system functionality, health knowledge, environmental influences, and cost (price).${ }^{13}$ However most research to date on the factors that influence demand for emergency healthcare has been derived from either a retrospective analysis of patients' records at hospital EDs or from surveys of patients attending EDs, and thus do not reflect broader community's perspectives.

“Citizen's Jury" or "Citizen's Council” approach is increasingly being used in healthcare priority-setting and decision making. ${ }^{14}$ However, the public perspective is often neglected in the management of the emergency healthcare system and in the identification of what models of care they feel may provide an acceptable alternative to attending EDs in order to alleviate the pressure put on this system. Various models of care have been suggested and/or trialled. ${ }^{15-}$

${ }^{20}$ However, the acceptability of those models to patients and the community is not known.

This is the peer reviewed version of the following article:

Fitzgerald, G., Toloo, G. S., Aitken, P., Keijzers, G., \& Scuffham, P. (2015). Public use and perceptions of emergency departments: A population survey. EMA - Emergency Medicine Australasia, 27(4), 336-342, which has been published in final form at https://doi.org/10.1111/1742-6723.12420 This article may be used for non-commercial purposes in accordance with Wiley Terms and Conditions for Use of Self-Archived Versions. 
The aim of this research was to identify public use of ED services and the reasons for that use along with perceptions of EDs, acceptable models of care, and the role played by various groups in policy-making in emergency healthcare. This public includes both users and nonusers of ED services and therefore reflects more broadly the general community's attitudes.

\section{Methods}

This research was conducted on behalf of the Queensland Health Statewide Emergency Department Network (SWEDN) Research sub-committee (Now: Queensland Emergency Research Collaborative) in collaboration with the School of Population Health at Griffith University and the Centre for Emergency and Disaster Management at the Queensland University of Technology (QUT). The group used the opportunity presented by the Queensland Social Survey (QSS) conducted by the Population Research Laboratory of the Institute for Health and Social Science at Central Queensland University. The QSS is an annual cost-shared, omnibus survey aimed at obtaining public opinion held by a random sample of Queensland residents on a range of topics. The SWEDN research sub-committee was able to provide additional questions for the 2012 survey which sought to identify the public perspectives of EDs, whether they had personal experience of that use or not.

The survey was conducted through a twenty station Computer-Assisted Telephone Interviewing (CATI) system over the period of 22 October 2012 to 23 November 2012. For sampling purposes, the State was divided into two areas: South-East Queensland (SEQ), and Remainder of Queensland. The sample size was determined by QSS as a minimum of 800 in SEQ and 400 for the rest. This was to ensure that with $95 \%$ confidence the overall survey estimates would be accurate within a sampling error of $\pm 2.8 \%$ assuming a binomial $50 / 50$ estimate proportion. The target population designated for telephone interviewing was all persons 18 years of age or older who, at the time of the survey, were living in a dwelling unit in Queensland that could be contacted by direct-dialled, land-based telephone service. A

This is the peer reviewed version of the following article:

Fitzgerald, G., Toloo, G. S., Aitken, P., Keijzers, G., \& Scuffham, P. (2015). Public use and perceptions of emergency departments: A population survey. EMA - Emergency Medicine Australasia, 27(4), 336-342, which has been published in final form at https://doi.org/10.1111/1742-6723.12420 This article may be used for non-commercial purposes in accordance with Wiley Terms and Conditions for Use of Self-Archived Versions. 
computer generated random selection process was used to ensure all respondents had an equal chance of being contacted. Once contacted, an algorithm was used to ensure balance of gender and region in Queensland.

The survey included a standard introduction, specific questions structured around the research interests of those who contributed to the survey in 2012 and standard demographic questions. The survey was approved by the CQ University Human Ethics Research Review Panel (H10/06-121, Queensland Social Survey 2012).

The questions related to this study were constructed around determining the attitudes of people (users or non-users) towards and reasons for the use of EDs, the role they should play in the health system, and towards possible alternatives to ED use. The questions about attitudes and reasons were adopted from our previous study on demand for emergency health services in Queensland (EHSQ). ${ }^{21}$ Other questions were developed by the authors based on the literature on demand management initiatives ${ }^{11}$ and their expert opinions, and pilot tested for face validity in an iterative process amongst emergency stake holders. Respondents were asked to comment on their experience and attitudes towards EDs in the following areas:

1. Number of times used EDs in the last twelve months; who made the decision to attend; and why they chose to attend the ED.

2. Attitudes towards enhancing the role of:

a. nurses or allied health staff to manage patients in the ED to improve the efficiency of EDs when safe to do so;

b. paramedics to advise diversion to a more appropriate service;

c. general practitioners in acute health care;

d. private hospital EDs and in particular on the requirements for funding private hospital ED attendance. 
3. Attitudes towards who should be engaged in public policy considerations in regard to emergency health care.

The actual questions used are included in Appendix One. This study focuses in particular on the factors influencing use of EDs.

Pearson's Chi-squared $\left(\chi^{2}\right)$ test at were used to assess the association between categorical variables. A p-value $<0.05$ was deemed statistically significant. All analyses were conducted in SPSS Statistics 21.0 (IBM Company, Chicago, Illinois).

\section{Results}

The final sample included a total of 1256 respondents (Response rate $=40.3 \%$ ), of whom twothirds were from South East Queensland and half were male, very close to the 2011 population characteristics (Table 1). The respondents were between 18 and 91 years old (median $=56$, Interquartile range $=44-67)$. Compared with the population, the $18-34$ years age group were under-represented while the 55+ were over-represented in the study sample. Regarding marital status, three-quarter of the respondents were married or in a de facto relationship, showing an over-representation compared to the general population, while the never married group were under-represented.

Overall, 21.4\% (95\% CI: 19.3-23.8\%) had used an ED at least once in the previous 12 months; $6.9 \%$ (95\% CI: 5.6-8.4\%) multiple times. Half the patients $(50.6 \%, 95 \%$ CI: $44.6-$ $56.5 \%$ ) made the decision themselves to attend the ED. For the other half, general practitioners $(17.6 \%, 95 \%$ CI: $13.5-22.6 \%)$, family, friends and co-workers $(17.6 \%, 95 \% \mathrm{CI}$ : 13.5-22.6\%), ambulance staff and other health practitioners (13.1\%, 95\% CI: 9.6-17.7\%) and others $(1.1 \%, 95 \%$ CI: $0.4-3.2 \%)$ were indicated as the persons who made the decision. As Table 2 shows, there were some differences by age group. Family, friends and co-workers 
were more likely to be principal decision makers for the 18-34 years age group than in other groups.

\section{[TABLE 2 ABOUT HERE]}

Table 3 shows the respondents' reasons for attending EDs by prioritising the three most important reasons. "Severity of the condition" and/or "lack of alternative health services" were the main reasons selected either as first or second choice. One in five selected "provision of better care" and "convenience of having all services in one place" as their third choice. Using Pearson's Chi-squared test, we examined whether the reasons for using ED was significantly different when the decision to attend the ED was made by the patient versus others, and found no statistically significant difference between the two groups.

\section{[TABLE 3 ABOUT HERE]}

Participants were asked about the role other health care providers can play to manage the increasing demand for EDs more efficiently. As Table 4 shows, about $76 \%$ of all the respondents strongly agreed or agreed that nurses and allied health professionals should have increased duties and responsibilities to treat patients where it is safe to do so in order to increase the efficiency of the ED. ED users were significantly more likely to disagree with this option than non-users $\left(22.7 \%\right.$ vs. $\left.16.5 \%, \chi^{2}=11.4 ; \mathrm{p} 0.02\right)$. More than three in every four respondents strongly agreed/agreed that, provided adequately trained, paramedics should have the ability to assess and treat patients on site or offer alternatives such as referral to a GP or health clinic when they considered it appropriate instead of transporting them to an ED. No statistically significant difference was found between ED users and non-users. Nearly $90 \%$ strongly agreed/agreed that private health insurance (PHI) should cover the costs of attending private EDs, and similar percentage strongly agreed/agreed that GPs should be given incentives to provide simple, minor procedures and wound care so that patients do not have to 
go to an ED for less serious injuries. The responses were not significantly different between ED users and non-users.

\section{[TABLE 4 ABOUT HERE]}

Table 5 shows the respondents' preferences about who they believed should be involved in the process setting policies and decisions for emergency health care services. Over a quarter of the respondents selected as their first choice the doctors and other healthcare professionals as the groups to be involved in this process. Eight percent selected health service managers as the first choice and $11.5 \%$ as the second choice. Around $16 \%$ selected informed members of the public or emergency health service users as their first or second choice. ED users were significantly more likely than non-users to select as their first choice the emergency health service users $(7.7 \%$ vs. $5.9 \%$, p 0.04$)$.

\section{[TABLE 5 ABOUT HERE]}

\section{Discussion}

In summary, one-fifth (21\%) of the participants had used ED services in twelve months prior to the survey. This estimate is higher than the $13.7 \%$ estimate by the Australian Bureau of Statistics (ABS). ${ }^{22}$ However, the two estimates are different in that the former covers Queensland and the latter Australia. Secondly, the respondents' age was $\geq 18$ years in our study compared to $\geq 15$ years in ABS survey. While it is not possible to derive an average number of attendances because of the inclusion of the option "four or more times", this is close to the average utilisation rate (total ED presentations per 100 population) in 2012 across Queensland of $35 \% .^{11,23}$

As previous research has identified, the reasons and decision to attend an ED is not straightforward, 7,9,11,13,22 and seems to happen within a constellation of perceptions and 
decision-making processes which involve different social actors and attitudes. Our study shows that the large majority of people attend EDs because they believe the severity of their conditions requires a healthcare service, which is best provided by the ED and its staff. Consistent with our study, the ABS survey also reported that for $50 \%$ the perceived severity of the condition was the main issue, and a further $13 \%$ said they were referred by GPs or GPs did not have the right facilities. ${ }^{22}$ Other reasons such as convenience, availability, accessibility, and financial constraints do play a role in their decisions, albeit to a much lesser extent. The ABS survey reported time of day or day of week (25.5\%) and long waiting time for GP appointment $(2.5 \%)$ as other reasons. ${ }^{22}$ The decision was made in half of the cases by patients and the other half by a wide range of people from family members to members of the public unknown to the patient. This has significance for health promotion programs directed towards patients. It also adds importance to the concern that much professional debate is directed towards the appropriateness of the patient's decision when in almost half the circumstances the patients did not actually make the decision, or at least not alone. However, due to relatively small numbers in each category, the differences should be interpreted cautiously.

Communities are facing increased challenges from growing demand for emergency care. ${ }^{23}$ This study is part of the research on the growth in demand for emergency health care and its contribution to the congestion being experienced by EDs across the nation. Although we appreciate that one of the most significant contributors to ED congestion is Access Block, ${ }^{6}$ we believe that demand management in isolation will fail to address the fundamental issue. ${ }^{24}$ Strategies such as the National Emergency Access Target (The Four Hour Rule) ${ }^{25}$ may moderate Access Block by concentrating whole of system attention, however it is unlikely to address the total capacity constraints in Australia's health system, which are the primary causes of the system congestion. 
Additionally, the increasing demand for the emergency health system, which is likely to be further compounded new challenges such as those posed by heatwaves and environmental disasters, ${ }^{26,27}$ require new approaches to ensure that our emergency health services are better positioned to cope with future challenges. New approaches are needed as some of the current policy responses (e.g. telephone call centres, collocated or after-hours GP services) have proven to be either ineffective or only marginally effective. ${ }^{19,20,28,29}$ These policies have been driven by targets rather than evidence, (e.g. NEAT) ${ }^{30}$ or have been based on prejudicial attitudes towards the patients (e.g. "inappropriate users") or the service providers. ${ }^{7,8}$

As our findings show, a multi-faceted and community-based approach is needed to understand the factors that drive the growth in demand and on a thorough testing and validation of alternative organisational and policy responses. One such approach lies in more flexible models of service delivery. This involves greater flexibility in the range and scope of services provided by individual health practitioners. Critical to that approach is a better understanding of the community's perspectives, their attitudes towards EDs generally and towards alternative models of care. ${ }^{14}$ This research reinforces previous research in Australia and elsewhere that the growth in demand for emergency healthcare is being driven by factors that are a complex admixture of demographic factors (the ageing population), epidemiological factors (the rates of chronic diseases), health system factors (access and availability of service delivery alternatives) and community attitudes. ${ }^{11}$ Most patients attend EDs because they perceive that their illness is of a nature that is best managed by the resources available there and that alternatives are not available, accessible or affordable. Although health professionals may disagree with patients' decision, it is unlikely that policies or guidelines will ever define the "appropriateness" of that decision and influence behaviours.

Therefore, in order to reduce the pressure being experienced by the emergency healthcare system across Australia, we need to develop new systems of emergency health care or

This is the peer reviewed version of the following article:

Fitzgerald, G., Toloo, G. S., Aitken, P., Keijzers, G., \& Scuffham, P. (2015). Public use and perceptions of emergency departments: A population survey. EMA - Emergency Medicine Australasia, 27(4), 336-342, which has been published in final form at https://doi.org/10.1111/1742-6723.12420. This article may be used for non-commercial purposes in accordance with Wiley Terms and Conditions for Use of Self-Archived Versions. 
redesign existing systems to more efficiently and effectively meet that demand. This research adds to that evidence base by noting that patients are generally accepting of more flexible models of service delivery. Further research is necessary to detail patient needs and to identify models of care which will better meet those needs safely.

\section{Limitations}

First, this survey understates the total utilisation rate as it did not address children who are known to constitute $30 \%$ of attendees. ${ }^{31}$ However, as a public survey it would have captured the parents of children who are the primary decision maker in that circumstance. Second, the nature of any survey, particularly telephone-based ones, is such that its structured nature limits the ability to explore issues in depth. Third, due to the retrospective design of the study, the chance of recall bias increases. Fourth, the sample was overall under-represented by age groups $<45$ years and over-represented by $45+$ years, which may impact its representativeness. This may in part be related to the use of landline telephones in CATI surveys, while a considerable proportion of the younger people only use mobile phones. And finally, some of the questions about alternative models of care and involvement of other people in decision and policy making could be interpreted as double-barrelled and were not externally validated. The findings should be interpreted within these limitations and any generalisation of the results is to be avoided.

\section{Conclusion}

This research is the first known study of the population attitudes to ED use and alternative models of care in Australia and complements previous research conducted at Queensland University of Technology into demand for emergency health services in Queensland and associated factors. People elect to seek urgent medical care at an ED because they consider their condition is appropriate to be treated there. Providing effective alternative models of

This is the peer reviewed version of the following article:

Fitzgerald, G., Toloo, G. S., Aitken, P., Keijzers, G., \& Scuffham, P. (2015). Public use and perceptions of emergency departments: A population survey. EMA - Emergency Medicine Australasia, 27(4), 336-342, which has been published in final form at https://doi.org/10.1111/1742-6723.12420. This article may be used for non-commercial purposes in accordance with Wiley Terms and Conditions for Use of Self-Archived Versions. 
care to reduce demand for ED services seem to be acceptable to most people, although some more than others. It appears that the public is highly in favour of options such as GP incentives, extending the private health insurance coverage, increased role definition for ambulance paramedics, and expanded roles for nurses and allied health practitioners. More focussed studies are recommended to evaluate the feasibility of implementing such policies.

\section{Acknowledgements}

The authors would like to acknowledge the funding provided by Queensland Health Statewide Emergency Department Network (SWEDN) Research committee (Now Queensland Emergency Research Collaborative- QERC) to conduct this survey. We also thank Ms Kylie Rixon, of Centre for Applied Health Economics at Griffith University for her input in developing the questionnaire. School of Population Health at Griffith University and the Centre for Emergency and Disaster Management at Queensland University of Technology also provided resources in support of conducting this study. 


\section{References}

1. Asplin BR, Magid DJ. If you want to fix crowding, start by fixing your hospital. Ann Emerg Med. 2007;49(3):273-4.

2. ACEM. Statement on Access Block (S127). Melbourne: Australasian College for Emergency Medicine; 2014 [updated March 2014; Accessed 1 Jun 2015]; Available from:

https://www.acem.org.au/getattachment/8c29d36e-27e2-40e7-9a1e-dfe73c5298ba/S127Statement-on-Access-Block.aspx.

3. Atzema C, Bandiera G, Schull MJ. Emergency Department Crowding: The Effect on Resident Education. Ann Emerg Med. 2005;45(3):276-81.

4. Bernstein S, Aronsky D, Duseja R, Epstein S. The Effect of Emergency Department Crowding on Clinically Oriented Outcomes. Acad Emerg Med. 2009;16:1-10.

5. Cowan RM, Trzeciak S. Clinical review: Emergency department overcrowding and the potential impact on the critically ill. Crit Care. 2005;9:291-5.

6. Fatovich DM, Nagree $Y$, Sprivulis P. Access block causes emergency department overcrowding and ambulance diversion in Perth,Western Australia. Emerg Med J. 2005;22:351-4.

7. Siminski P, Cragg S, Middleton R, Masso M, Lago L, Green J, et al. Primary care patients views on why they present to the Emergency Departments: Innapropriate attendances or inappropriate policy. Aust J Prim Health. 2005;11:87-95.

8. Vardy J, Mansbridge C, Ireland A. Are emergency department staffs' perceptions about the inappropriate use of ambulances, alcohol intoxication, verbal abuse and violence accurate? Emerg Med J. 2009;26:164-8.

9. Masso M, Bezzina AJ, Siminski P, Middleton R, Eagar K. Why patients attend emergency departments for conditions potentially appropriate for primary care: Reasons given by patients and clinicians differ. Emerg Med Australas. 2007;19:333-40.

10. Tregunno D, Baker RG, Barnsley J, Murray M. Competing values of emergency department performance: balancing multiple stakeholder perspectives. Health Serv Res. 2004;39(4 part 1):77192.

11. Toloo S, FitzGerald G, Aitken P, Ting J, Tippett V, Chu K. Emergency Health Services: Demand and Service Delivery Models. Monograph 1: Literature Review and Activity Trends. Brisbane: Queensland University of Technology; 2011.

12. FitzGerald G, Toloo S, Rego J, Ting J, Aitken P, Tippett V. Demand for public hospital emergency department services in Australia: 2000-2001 to 2009-2010. Emerg Med Australas. 2012;24:72-8.

13. Lowthian JA, Curtis AJ, Cameron PA, Stoelwinder JU, Cooke MW, McNeil JJ. Systematic review of trends in emergency department attendances: an Australian perspective. Emerg Med J. 2010;28(5):373-7.

14. Williams I, Robinson S, Dickinson H. Rationing in health care: the theory and practice of priority setting. Bristol, UK: The Policy Press; 2012.

15. Considine J, Martin R, Smit D, Winter C, Jenkins J. Emergency nurse practitioner care and emergency department patient flow: Case-control study. Emerg Med Australas. 2006;18:385-90.

16. Kinsman L, Champion R, Lee G, Martin M, Masman K, May E, et al. Assessing the impact of streaming in a regional emergency department. Emerg Med Australas. 2008;20:221-7.

17. Fry MM. Barriers and facilitators for successful after hours care model implementation: Reducing ED utilisation. Australasian Emergency Nursing Journal. 2009;12(4):137-44.

18. CAA. Expanding roles: An Australasian overview of emerging paramedic models of care. Adelaide: Council of Ambulance Authorities2008.

19. Hanson DW, Sadlier HR, Muller R. Bulk-billing GP clinics did not significantly reduce emergency department caseload in Mackay, Queensland. Med J Aust. 20047 June 2004 180:594. 20. O'Kelly FD, Teljeur C, Carter I, Plunkett PK. Impact of a GP cooperative on lower acuity emergency department attendances. Emerg Med J. 2010;27:770-3. 
21. Toloo S, Rego J, FitzGerald G, Vallmuur K, Ting J. Emergency Health Services: Demand and Service Delivery Models. Monograph 3: Patients' Reasons and Perceptions. Research Monograph. Brisbane: Queensland University of Technology2013. Report No.: 978-1-921897-93-1.

22. ABS. Patient Experiences in Australia: Summary of Findings, 2012-13. Canberra: Australian Bureau of Statistics2013 Contract No.: 48390DO001_201213.

23. FitzGerald G, Toloo S, Rego J, Ting J, Aitken P, Tippett V. Demand for public hospital emergency department services in Australia: 2000-2001 to 2009-2010. Emerg Med Australas. 2011.

24. Harris A, Sharma A. Access block and overcrowding in emergency departments: an empirical analysis. Emerg Med J. 2010;27:508-11.

25. ECI. NEAT - The Basics. Emergency Care Institute; 2013 [Accessed 3/10/2013]; Available from: http://www.ecinsw.com.au/NEAT-the-basics.

26. Toloo GS, Yu W, Aitken P, FitzGerald G, Tong S. The impact of heatwaves on emergency department visits in Brisbane, Australia: A time series study. Crit Care. 2014;18:R69.

27. Turner LR, Connell D, Tong S. Exposure to hot and cold temperatures and ambulance attendances in Brisbane, Australia: a time-series study. BMJ Open. 2013;2:e001074.

28. Buckley DJ, Curtis PW, McGirr JG. The effect of a general practice after-hours clinic on emergency department presentations: a regression time series analysis. Med J Aust. 2010;192(8):448-51.

29. Sprivulis P, Carey M, Rouse I. Compliance with advice and appropriateness of emergency presentation following contact with the HealthDirect telephone triage service. Emerg Med Australas. 2004;16:35-40.

30. Jones P, Schimanski K. The four hour target to reduce emergency department 'waiting time': A systematic review of clinical outcomes. Emerg Med Australas. 2010;22(5):391-8.

31. Toloo S, Rego J, FitzGerald G, Aitken P, Ting J, Quinn J, et al. Emergency Health Services: Demand and Service Delivery Models. Monograph 2: Queensland EHS Users' Profile. Research Monograph. Brisbane: Queensland University of Technology2012. Report No.: 978-1-921897-52-8. 32. ABS. 2011 Census of Population and Housing: Expanded Community Profile. Cat No. 2005.0: Australian Bureau of Statistics2012. 


\section{TABLES}

Table 1 Comparison between the study sample and population characteristics

\begin{tabular}{|l|c|c|c|}
\hline Characteristic & $\begin{array}{c}\text { Sample } \\
(\%)^{1}\end{array}$ & $\begin{array}{c}\text { Population } \\
\text { (\%) }\end{array}$ & Difference \\
\hline Location & 67.1 & 66.5 & 0.6 \\
South-east Queensland & 32.9 & 33.5 & -0.6 \\
Rest of State & 50.3 & 49.6 & 0.7 \\
\hline Gender & 49.7 & 50.4 & -0.7 \\
Male & & & \\
Female & 4.0 & 12.5 & -8.5 \\
\hline Age group & 6.2 & 17.9 & -11.7 \\
18-24 & 15.0 & 18.9 & -3.9 \\
25-34 & 21.3 & 18.0 & 3.3 \\
35-44 & 22.9 & 15.3 & 7.6 \\
45-54 & 29.7 & 17.4 & 12.3 \\
55-64 & & & \\
65,+ & 75.4 & 47.9 & 27.5 \\
\hline Marital Status & 7.2 & 12.4 & -5.2 \\
Married/ De facto & 6.5 & 5.0 & 1.5 \\
Separated/ Divorced & 10.4 & 34.7 & -24.3 \\
Widowed & & & \\
Never married & 78.3 & 73.7 & 4.6 \\
\hline Country of birth & 21.0 & 27.3 & -6.3 \\
\hline Australia & & & \\
Other & 2.0 & 4.2 & -2.2 \\
\hline Aboriginal status & 96.8 & 95.8 & 1.0 \\
Aboriginal/ Islander & & & \\
Non-Aboriginal & 24.0 & 27.1 & -3.1 \\
\hline Household Income & 14.1 & 29.3 & -15.2 \\
<\$1000 per week & 24.9 & 31.3 & -6.4 \\
\$1000 - \$1999 per week & $\mathbf{1 , 2 5 6}$ & $\mathbf{4 , 4 7 6 , 7 7 8}$ & -- \\
\hline \$2000 - \$2999 per week & & & \\
\hline Total (n) & & & \\
\hline Note: Where the sum of & & & \\
\hline
\end{tabular}

Note: Where the sum of percentages does not equal 100, the balance is "Don't know" or "No answer".

This is the peer reviewed version of the following article:

Fitzgerald, G., Toloo, G. S., Aitken, P., Keijzers, G., \& Scuffham, P. (2015). Public use and perceptions of emergency departments: A population survey. EMA - Emergency Medicine Australasia, 27(4), 336-342, which has been published in final form at https://doi.org/10.1111/1742-6723.12420. This article may be used for non-commercial purposes in accordance with Wiley Terms and Conditions for Use of Self-Archived Versions. 
Table 2 Principal decision maker to visit ED (by Age group)

\begin{tabular}{|c|c|c|c|c|c|c|}
\hline $\begin{array}{l}\text { Age } \\
\text { group }\end{array}$ & $\begin{array}{c}\text { Respondent } \\
\%(95 \% \mathrm{Cl})\end{array}$ & $\begin{array}{l}\text { Family/ } \\
\text { Friend/ } \\
\text { Co-worker } \\
\%(95 \% \mathrm{Cl})\end{array}$ & $\begin{array}{c}\text { General } \\
\text { practitioner } \\
\%(95 \% \mathrm{Cl})\end{array}$ & $\begin{array}{c}\text { Other health } \\
\text { professionals } \\
\%(95 \% \mathrm{Cl})\end{array}$ & $\begin{array}{c}\text { Others/ } \\
\text { bystanders } \\
\%(95 \% \mathrm{Cl})\end{array}$ & $\chi^{2}(p)^{*}$ \\
\hline $18-34$ & $\begin{array}{r}8.2 \\
(4.6-14.1)\end{array}$ & $\begin{array}{r}30.4 \\
(19.1-44.8)\end{array}$ & $\begin{array}{r}2.2 \\
(0.4-11.3)\end{array}$ & $\begin{array}{r}5.7 \\
(1.6-18.6)\end{array}$ & $\begin{array}{r}33.3 \\
(6.1-79.2)\end{array}$ & \\
\hline $35-44$ & $\begin{array}{r}19.4 \\
(13.6-26.9)\end{array}$ & $\begin{array}{r}4.3 \\
(1.2-14.5)\end{array}$ & $\begin{array}{r}13.0 \\
(6.1-25.7)\end{array}$ & $\begin{array}{r}14.3 \\
(6.3-29.4)\end{array}$ & $\begin{array}{r}33.3 \\
(6.1-79.2)\end{array}$ & 32.2 \\
\hline $45-54$ & $\begin{array}{r}23.1 \\
(16.8-31.0)\end{array}$ & $\begin{array}{r}13.0 \\
(6.1-25.7)\end{array}$ & $\begin{array}{r}21.7 \\
(12.3-35.6)\end{array}$ & $\begin{array}{r}22.9 \\
(12.1-39.0)\end{array}$ & $\begin{array}{r}0.0 \\
(0.0-56.2)\end{array}$ & $(0.001)$ \\
\hline $55+$ & $\begin{array}{r}49.3 \\
(40.9-57.6) \\
\end{array}$ & $\begin{array}{r}52.2 \\
(38.1-65.9) \\
\end{array}$ & $\begin{array}{r}63.0 \\
(48.6-75.5) \\
\end{array}$ & $\begin{array}{r}57.1 \\
(40.8-72.0) \\
\end{array}$ & $\begin{array}{r}33.3 \\
(6.1-79.2) \\
\end{array}$ & \\
\hline Total (n) & 134 & 46 & 46 & 35 & 3 & \\
\hline
\end{tabular}

* Note: $25 \%$ of cells have expected count $<5$. 
Table 3 Respondents' reasons for using ED

\begin{tabular}{lccc}
\hline Reason & $\begin{array}{c}\text { First } \\
\text { choice } \\
(\%)\end{array}$ & $\begin{array}{c}\text { Second } \\
\text { choice } \\
(\%)\end{array}$ & $\begin{array}{c}\text { Third } \\
\text { choice } \\
(\%)\end{array}$ \\
\hline My condition was too severe to go elsewhere. & 47.1 & 21.3 & 13.0 \\
No other health services were available at the time. & 26.1 & 32.2 & 10.9 \\
The hospital will provide better care for my condition. & 11.1 & 13.9 & 20.7 \\
It is convenient to have all facilities in one place in the & 6.5 & 13.9 & 21.2 \\
hospital. & & & \\
The hospital is close by and easily accessible. & 5.0 & 8.3 & 10.3 \\
Hospital doctors and nurses are better specialised than GPs. & 3.4 & 4.8 & 15.8 \\
Hospital services are free. & 0.8 & 5.7 & 8.2 \\
\hline Total $(\mathbf{n})$ & $\mathbf{2 6 1}$ & $\mathbf{2 3 0}$ & $\mathbf{1 8 4}$ \\
\hline
\end{tabular}

Note: Responses have been sorted based on the first choice. 
Table 4 Respondents' opinion of alternative methods to reduce ED use

\begin{tabular}{|c|c|c|c|c|c|c|c|c|c|}
\hline \multirow[b]{2}{*}{ Model of care } & \multicolumn{4}{|c|}{ Non-users } & \multicolumn{4}{|c|}{ ED users } & \multirow[b]{2}{*}{$\chi^{2}(p)$} \\
\hline & $\begin{array}{c}\text { Strongly } \\
\text { agree/ } \\
\text { Agree } \\
\%(95 \% \mathrm{Cl}) \\
\end{array}$ & $\begin{array}{c}\text { Neither } \\
\text { agree nor } \\
\text { disagree } \\
\%(95 \% \mathrm{Cl})\end{array}$ & $\begin{array}{c}\text { Strongly } \\
\text { disagree/ } \\
\text { Disagree } \\
\%(95 \% \mathrm{Cl}) \\
\end{array}$ & $\begin{array}{c}\text { Total } \\
(n)\end{array}$ & $\begin{array}{c}\text { Strongly } \\
\text { agree/ } \\
\text { Agree } \\
\%(95 \% \mathrm{Cl}) \\
\end{array}$ & $\begin{array}{c}\text { Neither } \\
\text { agree nor } \\
\text { disagree } \\
\%(95 \% \mathrm{Cl}) \\
\end{array}$ & $\begin{array}{c}\text { Strongly } \\
\text { disagree/ } \\
\text { Disagree } \\
\%(95 \% \mathrm{Cl}) \\
\end{array}$ & $\begin{array}{c}\text { Total } \\
(\mathrm{n})\end{array}$ & \\
\hline $\begin{array}{l}\text { Increased role for nurses \& } \\
\text { allied health, if safe to do so }\end{array}$ & $\begin{array}{c}77.5 \\
(74.7-80.1)\end{array}$ & $\begin{array}{c}6.9 \\
(5.4-8.7)\end{array}$ & $\begin{array}{c}15.6 \\
(13.4-18.0)\end{array}$ & 943 & $\begin{array}{c}70.0 \\
(64.3-75.3)\end{array}$ & $\begin{array}{c}7.2 \\
(4.7-11.0)\end{array}$ & $\begin{array}{c}22.7 \\
(18.1-28.2)\end{array}$ & 264 & $11.40(0.02)$ \\
\hline $\begin{array}{l}\text { - Paramedics treat at scene, if } \\
\text { adequately trained }\end{array}$ & $\begin{array}{c}79.2 \\
(76.5-81.6)\end{array}$ & $\begin{array}{c}4.7 \\
(3.5-6.2)\end{array}$ & $\begin{array}{c}16.1 \\
(14.0-18.6)\end{array}$ & 960 & $\begin{array}{c}74.1 \\
(68.5-79.1)\end{array}$ & $\begin{array}{c}7.6 \\
(5.0-11.5)\end{array}$ & $\begin{array}{c}18.3 \\
(14.0-23.4)\end{array}$ & 263 & $7.36(0.12)$ \\
\hline $\begin{array}{l}\text { - Paramedics transfer to GP/ } \\
\text { services other than ED }\end{array}$ & $\begin{array}{c}78.2 \\
(75.5-80.7)\end{array}$ & $\begin{array}{c}5.1 \\
(3.8-6.6)\end{array}$ & $\begin{array}{c}16.7 \\
(14.5-19.2)\end{array}$ & 968 & $\begin{array}{c}75.8 \\
(70.2-80.6)\end{array}$ & $\begin{array}{c}4.6 \\
(2.7-7.9)\end{array}$ & $\begin{array}{c}19.6 \\
(15.3-24.9)\end{array}$ & 260 & $5.53(0.24)$ \\
\hline - Private ED coverage by PHI & $\begin{array}{c}90.7 \\
(88.7-92.4)\end{array}$ & $\begin{array}{c}3.2 \\
(2.9-5.4)\end{array}$ & $\begin{array}{c}5.3 \\
(4.1-7.0)\end{array}$ & 938 & $\begin{array}{c}85.9 \\
(81.2-89.7)\end{array}$ & $\begin{array}{c}5.9 \\
(3.6-9.4)\end{array}$ & $\begin{array}{c}8.2 \\
(5.4-12.2)\end{array}$ & 256 & $6.41(0.17)$ \\
\hline - Incentives for GPs & $\begin{array}{c}90.3 \\
(88.3-92.0)\end{array}$ & $\begin{array}{c}3.4 \\
(2.4-4.7)\end{array}$ & $\begin{array}{c}6.3 \\
(5.0-8.1)\end{array}$ & 962 & $\begin{array}{c}89.5 \\
(85.2-92.6)\end{array}$ & $\begin{array}{c}4.5 \\
(2.6-7.7)\end{array}$ & $\begin{array}{c}6.0 \\
(3.7-9.5)\end{array}$ & 266 & $1.15(0.89)$ \\
\hline
\end{tabular}


Table 5 Respondents' preferences regarding involvement of various groups in making decisions and policies

\begin{tabular}{|c|c|c|c|c|c|c|}
\hline \multirow{2}{*}{$\begin{array}{r}\text { Preference } \\
\text { No. of times used ED in past year }\end{array}$} & \multicolumn{3}{|c|}{ First choice } & \multicolumn{3}{|c|}{ Second choice } \\
\hline & $\begin{array}{c}\text { None } \\
\%(95 \% \mathrm{Cl})\end{array}$ & $\begin{array}{c}\geq \text { Once } \\
\%(95 \% \mathrm{Cl})\end{array}$ & $\chi^{2}(p)$ & $\begin{array}{c}\text { None } \\
\%(95 \% \mathrm{Cl})\end{array}$ & $\begin{array}{c}\geq \text { Once } \\
\%(95 \% \mathrm{Cl})\end{array}$ & $\chi^{2}(p)$ \\
\hline Doctors & $\begin{array}{r}56.0 \\
(52.7-59.2)\end{array}$ & $\begin{array}{r}52.2 \\
(46.0-58.4)\end{array}$ & $0.94(0.19)$ & $\begin{array}{r}24.7 \\
(22.0-27.7)\end{array}$ & $\begin{array}{r}27.7 \\
(22.4-33.6)\end{array}$ & $1.66(.11)$ \\
\hline Other healthcare professionals & $\begin{array}{r}21.1 \\
(18.6-23.8)\end{array}$ & $\begin{array}{r}20.6 \\
(16.1-26.1)\end{array}$ & $0.15(0.37)$ & $\begin{array}{r}47.2 \\
(43.9-50.4)\end{array}$ & $\begin{array}{r}48.3 \\
(42.1-54.6)\end{array}$ & $0.08(.42)$ \\
\hline Managers of health services & $\begin{array}{r}7.9 \\
(6.3-9.9)\end{array}$ & $\begin{array}{r}8.9 \\
(6.0-13.1)\end{array}$ & $0.03(0.49)$ & $\begin{array}{r}11.6 \\
(9.7-13.8)\end{array}$ & $\begin{array}{r}11.2 \\
(7.8-15.7)\end{array}$ & $0.17(.38)$ \\
\hline Informed members of the public & $\begin{array}{r}9.1 \\
(7.4-11.2)\end{array}$ & $\begin{array}{r}10.5 \\
(7.3-15.0)\end{array}$ & $0.01(0.53)$ & $\begin{array}{r}8.5 \\
(6.8-10.5)\end{array}$ & $\begin{array}{r}8.3 \\
(5.4-12.7)\end{array}$ & $0.33(.32)$ \\
\hline Emergency health service users & $\begin{array}{r}5.9 \\
(4.5-7.6) \\
\end{array}$ & $\begin{array}{r}7.7 \\
(5.0-11.7) \\
\end{array}$ & $3.35(0.04)$ & $\begin{array}{r}8.0 \\
(6.4-10.0) \\
\end{array}$ & $\begin{array}{r}4.5 \\
(2.6-8.0) \\
\end{array}$ & $0.95(.20)$ \\
\hline Total (n) & 920 & 247 & & 897 & 242 & \\
\hline
\end{tabular}




\section{Appendix}

\section{ED Perceptions in QLD: Final Survey Questions}

\section{Q:QED1}

Now the next few questions will ask about your experiences with Hospital Emergency Departments (EDs). During the past 12 months, how many times have you attended a hospital Emergency Department (ED) for medical treatment for YOURSELF?

[READ OPTIONS 1-5 IF NECESSARY]

1. Not in the past 12 months

2. Once

3. Twice

4. Three times

5. Four or more times

DO NOT READ

6. Don't know/Unsure

7. No response

If (answer <2) skip to QED2a

If (answer >5) skip to QED2a

Q: QED1b

Thinking about your most recent visit to the ED in the past year, WHO made the decision for you to go to the Emergency Department at this time?

[READ OPTIONS 1-6 IF NECESSARY]

1. It was my decision

2. Other family members/friends decided

3. People at my workplace decided

4. My GP decided

5. Ambulance staff decided

6. I called 13HEALTH and they recommended

7. Other (please specify)

DO NOT READ

8. Don't know/Unsure

9. No response

If (answer <7) skip to QED2a

If (answer >7) skip to QED2a

Q: QED1c

Who was the other person/s that made this decision?

\section{Q: QED2a}

There are a variety of reasons people mention about why they decide to attend a hospital ED. I will read you a list of common reasons and I'd like you to tell me which of these would be the MOST IMPORTANT to YOU in your choice to attend a hospital Emergency Department. In other words, what would be the MAIN reason YOU would make this decision?

[READ ALL ITEMS CLEARLY]

1. If my condition was too severe to go elsewhere.

2. If no other health services were available at the time.

3. It's convenient to have all facilities in one place in the hospital.

4. Hospital services are free.

5. Hospital doctors and nurses are better specialised than GPs.

6. The hospital is close by and easily accessible.

7. The hospital will provide better care for my condition.

8. Unsure/No response

If (answer $=8$ ) skip to QED3a 
Q: QED2b

Which of those reasons would be the SECOND MOST IMPORTANT to you in your choice to attend a hospital ED?

[REPEAT ITEMS IF NECESSARY - NOTE PREVIOUS CHOICE MISSING]

1. If my condition was too severe to go elsewhere.

2. If no other health services were available at the time.

3. It's convenient to have all facilities in one place in the hospital.

4. Hospital services are free.

5. Hospital doctors and nurses are better specialised than GPs.

6. The hospital is close by and easily accessible.

7. The hospital will provide better care for my condition.

8. Unsure/No response

If (answer $=8$ ) skip to QED3a

Q: QED2c

And which of those reasons would be the THIRD MOST IMPORTANT to you in your choice to attend a hospital ED?

[REPEAT ITEMS IF NECESSARY- NOTE PREVIOUS CHOICES MISSING]

1. If my condition was too severe to go elsewhere.

2. If no other health services were available at the time.

3. It's convenient to have all facilities in one place in the hospital.

4. Hospital services are free.

5. Hospital doctors and nurses are better specialised than GPs.

6. The hospital is close by and easily accessible.

7. The hospital will provide better care for my condition.

8. Unsure/No response

If (answer $=8$ ) skip to QED3a

Q: QED3a

We would now like to know about your general views on the way that hospital Emergency Departments operate. I will read you a series of statements and I would like you to tell me whether you strongly agree, agree, neither agree nor disagree, disagree or strongly disagree. There are no right or wrong answer answers to these questions, we are simply seeking your opinions.

The first statement is:

Nurses and allied health professionals should have increased duties and responsibilities to treat patients where it is safe to do so, in order to increase the efficiency of the ED.

[READ OPTIONS 1-5 IF NECESSARY]

1. Strongly agree

2. Agree

3. Neither agree nor disagree

4. Disagree

5. Strongly disagree

DO NOT READ

6. Don't know/Unsure

7. No response

Q: QED3b

Provided that paramedics are adequately trained to make assessments and offer treatment, they should be able to treat patients at the site, WITHOUT taking them to an ED.

[READ OPTIONS 1-5 IF NECESSARY]

1. Strongly agree

2. Agree

3. Neither agree nor disagree

4. Disagree

5. Strongly disagree

DO NOT READ

6. Don't know/Unsure

7. No response

This is the peer reviewed version of the following article:

Fitzgerald, G., Toloo, G. S., Aitken, P., Keijzers, G., \& Scuffham, P. (2015). Public use and perceptions of emergency departments: A population survey. EMA - Emergency Medicine Australasia, 27(4), 336-342, which has been published in final form at https://doi.org/10.1111/1742-6723.12420. This article may be used for non-commercial purposes in accordance with Wiley Terms and Conditions for Use of Self-Archived Versions. 
Q: QED3c

Paramedics should be able to take patients to a GP or other health clinics rather than an ED, if they judge that is the best place for that type of injury or illness.

[READ OPTIONS 1-5 IF NECESSARY]

1. Strongly agree

2. Agree

3. Neither agree nor disagree

4. Disagree

5. Strongly disagree

DO NOT READ

6. Don't know/Unsure

7. No response

Q: QED3d

Private health insurance should cover the cost of emergency care in PRIVATE hospitals.

[READ OPTIONS 1-5 IF NECESSARY]

1. Strongly agree

2. Agree

3. Neither agree nor disagree

4. Disagree

5. Strongly disagree

DO NOT READ

6. Don't know/Unsure

7. No response

Q: QED3e

GPs should be given incentives to provide simple, minor procedures and wound care so that patients do not have to go to an ED for less serious injuries.

[READ OPTIONS 1-5 IF NECESSARY]

1. Strongly agree

2. Agree

3. Neither agree nor disagree

4. Disagree

5. Strongly disagree

DO NOT READ

6. Don't know/Unsure

7. No response

Q: QED4a

When policies and decisions are made about how emergency health care services are organised and funded there are several groups who may provide input.

I will read you a list of groups now and I would like you to tell me which groups' preferences you think should be MOST important when these policies and decisions are being made about emergency health care services.

[READ ALL ITEMS CLEARLY]

1. Members of the general public who are informed and interested.

2. Managers of health services.

3. Doctors.

4. Other healthcare professionals such as ambulance officers and nurses.

5. People likely to use emergency health services more-ongoing health condition.

6. Unsure/No response

If (answer =6) skip to END SECTION

Q: QED4b

And which groups' preferences you think should be the NEXT MOST important for decision making in emergency health care?

[REPEAT ITEMS IF NECESSARY- NOTE PREVIOUS CHOICE MISSING]

1. Members of the general public who are informed and interested.

2. Managers of health services.

3. Doctors.

4. Other healthcare professionals such as ambulance officers and nurses.

5. People likely to use emergency health services more-ongoing health condition.

6. Unsure/No response

This is the peer reviewed version of the following article:

Fitzgerald, G., Toloo, G. S., Aitken, P., Keijzers, G., \& Scuffham, P. (2015). Public use and perceptions of emergency departments: A population survey. EMA - Emergency Medicine Australasia, 27(4), 336-342, which has been published in final form at https://doi.org/10.1111/1742-6723.12420. This article may be used for non-commercial purposes in accordance with Wiley Terms and Conditions for Use of Self-Archived Versions. 